\title{
The Impact of Aircraft Spare Parts Import Duty Exemption on the MRO Industry's Competitiveness and Its Services Export
}

\author{
Farida Rahmawati \\ Trade Analysis and Development Agency \\ Ministry of Trade \\ Jakarta, Indonesia \\ faridarahma13@gmail.com \\ Herindra Adhi Nusantara \\ Trade Analysis and Development Agency \\ Ministry of Trade \\ Jakarta, Indonesia \\ herindraadhi@gmail.com
}

\author{
Choirin Nisaa' \\ Trade Analysis and Development Agency \\ Ministry of Trade \\ Jakarta, Indonesia \\ choirin.nisaa@gmail.com \\ Rizka Isditami Syarif \\ Trade Analysis and Development Agency \\ Ministry of Trade \\ Jakarta, Indonesia \\ rizkasdisy@gmail.com
}

\begin{abstract}
This study aims to identify the impact of import duty exemption on aircraft spare parts on the competitiveness and service export of the Aircraft Maintenance, Reparation, and Overhaul (MRO) industry including factors affected MRO competitiveness. In addition, this study aims to identify the problems encountered during the implementation of the policy, the types of aircraft parts to be exempted and the criteria for products to be eligible for exemption from import duties. The method of this study used qualitative and quantitative descriptive analysis, Porter's five-force model and Analytical Hierarchy Process (AHP). The results of the study showed that the import duty exemption policy increased MRO services from 30 percent to 49 percent during 2013-2017. Constraints in implementation are procedures and differences in customs areas where the longest is for bonded zones. Special customs policies for MROs as well as the exemption of import duties for goods related to MROs which 90 percent originating from imports will greatly encourage competitiveness which relies heavily on aircraft down time. The types of goods that need to be exempted from import duties are consumable and repairable groups in both new and non-new capital goods categories. duty

Keywords-MRO, Porter's Five Force Model, AHP, import
\end{abstract}

\section{INTRODUCTION}

The Economic Policy Package VIII issued by The Government of Indonesia included the reduction of import tariffs for 21 tariff posts related to the List of Goods and Materials to Repair and/or Maintenance of Aircraft from a total of 300 tariff posts for aircraft parts. This policy was taken as a support for increasing competitiveness for the aircraft's Maintenance, Repair and Overhaul (MRO) industries. The increase in demand for air travel in 20182028 mostly occurs in airlines in emerging markets, including Asia with an estimated growth in the Revenue Passenger Kilometer (RPK) of 5.7\% [1]. The aviation industry had growth in terms of passengers, number of airlines, aircraft, flight routes and airports. During 19902016, the number of passengers increased from 9 million to 90 million. While the number of aircraft increased from 102 in 1990 to 1,030 aircraft in 2017. However, of the total aircraft operated by domestic airlines, only about $30 \%$ have been absorbed by domestic MROs. That is, the domestic market niche is still wide open. In the Asia Pacific region, there is potential for Indonesia's MRO industry to grow and take the market gap. In 2016, Indonesia's MRO market size is still valued at USD 970 million. Projected, based on the growth of domestically operated aircraft, the domestic MRO market value is USD 2.2 billion in $2025^{1}$. Indonesian Aircraft Maintenance Service Association (IAMSA) stated that domestic MRO grew by $9.6 \%$ per year or the second largest after India's average growth of $10 \%$ over the last five years ${ }^{2}$. The low market value of domestic MROs is allegedly due to the lack of competitiveness compared to neighboring MROs, Malaysia and Singapore. The reason is besides the internal factor constraints, also by the constraints of the availability of aircraft parts which are exclusive commodities and $99 \%$ are imported. Azka and Nurcahyo [2] conducted a study on the quality management strategy of Indonesian aircraft MRO companies to serve the needs of airlines customers aircraft maintenance. The main role of the MRO is to provide highservice aircraft with minimum costs and optimal quality [3], this is an opportunity for MRO companies to compete in offering airlines maintenance services since most airlines still outsource their aircraft maintenance [3,4], so MRO companies should be able to implement the right strategy to gain new markets and customers globally. This should be supported by the availability of aircraft spare parts. Through PMK No.35/2016, the Indonesian Government lowered the 21 tariff posts (HS 8 digits) to $0 \%$. Nonetheless, the MRO industry stated that there was a need to improve the policy of elimination of customs duties aircraft spare parts as there are constraints in the import policy implementation mechanisms, it is also necessary to add additional tariff posts exempted import duties. This study aims to identify the impact of import duty exemption on aircraft spare parts on the competitiveness and service export of the aircraft MRO industry including factors affected MRO competitiveness. In addition, this study aims to identify the problems encountered during the implementation of the policy, the types of aircraft parts to be exempted and the criteria for products to be eligible for exemption from import duties. 


\section{RESEARCH METHODOLOGY}

\section{A. Descriptive Analysis Approach}

The data was analyzed using descriptive statistics to obtain an overview of the development of aircraft spare parts imports, the development of the MRO industry in Indonesia and competing countries, either by using secondary data, surveys and roundtable discussions. Data is presented in tabular, charts and diagrams.

\section{B. Porter's Five Force Analysis}

The competitiveness examined in this study is Porter's competitiveness model, using a descriptive approach. According to Porter [5], a country gains a competitive advantage if the company (in that country) is competitive. There are five determinants competitiveness of an interacting industry: the existence of competitor industries, demand conditions, condition of production factor suppliers, potential threats from new industries, and the threat of substitute products. These factors are important for the industry to formulate the right strategies in the market [6]. Five forces determinants of MRO industry competitiveness are: threats of new MRO industry, supplier bargaining position, bargaining position of MRO users, and threat of substitution MRO services. According to Porter [7], the government does not include as a force, because the government, through its policies, has no effect (positive or negative) on the company's profits. The government's policy on competitiveness is seen as influencing five industrial forces. For example, patent rights affect barriers to entry encourage industrial development and potential profits. The government affects several levels, through different policies.

\section{Analytical Hierarchy Process (AHP) Analysis}

The AHP method is used to formulate recommendations on the tariff exemption policy for importing aircraft parts. Data processing of the priority strategy in the AHP method using Expert Choice 2008 software. AHP was developed by Saaty [8] that can solve complex problems with quite a lot of aspects or criteria taken. Basically, the mathematical formulation of the AHP model is done by using a matrix. For example, in an operating system there are $\mathrm{n}$ operating elements, namely operating elements $\mathrm{A} 1, \mathrm{~A} 2, \ldots, \mathrm{An}$, then the results of pairwise comparisons of the operating elements will form a comparison matrix. Pairwise comparisons starting from the highest hierarchical level where a criterion used as the basis for comparison. Then consider the elements to be compared. The weight matrix obtained from the paired comparison results must have the cardinal and ordinal relationship. Deviations from consistency are expressed as Consistency Indexes. Consistency measurement is expressed through an index called 'consistency index' (CI), as for CI formula

$C I=\left(\lambda_{\text {maks }}-n\right) / n-1$

where $\lambda$ maks is maximum eigenvalue and $n$ is matrix size. Random matrix consistency index (CI) with a rating scale of 9 (1 to 9) and the reverse as Random Index (RI). By using the amount of CI and RI, it can be used a criterion for determining the consistency of a matrix, which is called 'consistency ratio' [8]

$C R=C I / R I$ where $C R$ is consistency ratio, $C I$ is consistency index, and $R I$ is Random Index. For AHP model, comparison matrix can be accepted if the value of Consistency Ratio (CR) $\leq 0,1$ [9]. The AHP hierarchy is composed of four levels which show the stages of the priority process for spare parts to be exempt from the tariff, starting from the determination of focus on level 1, the alternative groups of spare parts proposed, the results of in-depth interviews and FGD. Level 2 is an actor involved in the use of spare parts. Level 3 is a factor considered in the selection of parts. Level 4 is the focus (goal), the group of selected parts based on the weighting value of the respondents.

\section{RESULT AND DISCUSSION}

In Indonesia, there are 64 AMO-certified domestic MROs and 84 foreign MROs companies. Domestic MRO companies are members of the IAMSA. Currently the domestic MROs absorb only $51 \%$ of the domestic market where GMF handles 34\%, BAT handle $14 \%$ and $3 \%$ were handled by other MRO [1]. While the remaining $49 \%$ use foreign MRO services. The existing MRO industry is supported by aircraft component companies joining the Indonesian Aircraft and Component Manufacturer Association with 30 companies member, and only 8 companies engaged in Aerospace Part Machining.

\section{A. The Impact of Aircraft Spare Parts Import Duty Exemption on the MRO Industry's Competitiveness}

Transactions in domestic MRO businesses all use USD currency, both aircraft managed by foreign airlines and domestic airlines. The use of domestic MRO services by domestic airlines means that there is import substitution for MRO services so that it can save foreign exchange. The use of domestic MRO services by foreign airlines is a form of MRO service exports, which generates foreign exchange. Increased domestic MRO services reflected by increased imports of aircraft components, as much as $99 \%$ of it is an imported commodity. Imported aircraft components will automatically increase if domestic MRO services increase. Figure 1 shows the aircraft component imports performance before and after the zero percent tariff reduction. Imports had declined in the last quarter of 2014 to the first quarter of 2016, a slight increase after the zero percent tariff policy was implemented, even though it was still below the initial import achievements in 2014 were over USD 5 million.

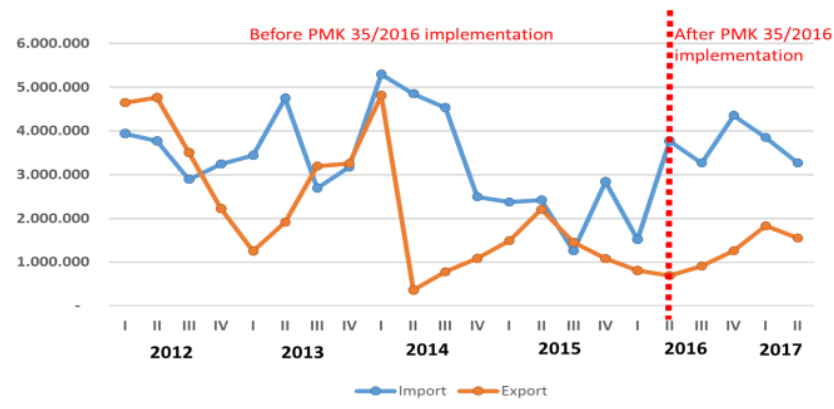

Fig. 1. Export-Import Performance of Aircraft Components

At the MRO level, the increase in competitiveness after the import duty exemption policy, as can be seen from the domestic MRO contribution in the aircraft belonging to the national airline (excluding public property and military 
aircraft). MRO with the capability of maintaining the mature generation aircraft, competitiveness increased with the exemption of import duties on aircraft spare parts. In 2013 the national MRO contribution only reached 30\%, in 2016 increased to $49 \%$. In 2017 the national MRO contribution has reached $51 \%$ or USD 1.1 billion, the remaining $49 \%$ using foreign MRO such as in Singapore, Malaysia, Hong Kong and so on. Of the entire national MROs, GMF contributed $67 \%$, BAT $30 \%$ and the rest were other MROs such as FL Technics, Indopelita Aircraft Service and Sriwijaya Maintenance Facility. National MRO services exports can be seen from the use of national MRO by foreign airlines. MRO services export is the use of national MRO by foreign airlines. Decreasing import duty on spare parts to $0 \%$ does not directly affect the MRO service exports, because currently the foreign airlines have enjoyed the $0 \%$ tariff facility (import policy for export purposes). Decreasing import duties on aircraft parts, opens up the opportunities for MRO to develop its capabilities, especially airframe modification capacities that are relatively labor intensive. Foreign airlines choose national MROs because the wages of labor in Indonesia are $50 \%$ of the wages of workers in foreign MROs.

\section{B. Constraints on Import Duty Exemption Policy Implementation}

\section{a) Administrative Procedure for Tariff Exemption Submission}

The main problem facing the MRO industry is the long administrative process to obtain a $0 \%$ tariff facility so that it had an impact on not achieving the minimum aircraft downtime. Furthermore, the cost of aircraft downtime borne by the customer for administrative processes is higher compared to the tariff facilities that can be saved. MRO in the FTZ area can take advantage of the zero percent tariff facility easier so it can be achieved minimum aircraft downtime. However, this facility is only for aircraft operating outside Indonesia (similar with re-exported goods treatment). For aircraft operating in domestic areas (PK aircraft), customers are still required to apply for import tariff exemptions. The treatment for MROs in bonded areas is when the goods will be used by the customer (for aircraft repairs), the customer must take care of the $0 \%$ tariff exemption. It takes 2-3 days for the submission process until the tariff exemption agreement before the plane can take off. For MRO in the PLB area, goods from the port directly enter the MRO warehouse. Goods can be directly installed on the aircraft, administration of tariff exemptions can be done later by the customer. Therefore the aircraft can operate immediately so that it can achieve minimum aircraft downtime. The process of inspecting goods and documents in ports for MROs that are not included in the special economic zone area takes five to twenty days (still in the red/yellow lane).

\section{b) Incompatibility of Non-Tariff Components with Customer Needs}

The proposed aircraft components to lowered tariffs to $0 \%$ has not been based on needs analysis. Of the $27 \mathrm{HS}$ components proposed in 2016 (25 HS is approved), determined based on the HS description containing the word "for aircrafts" so that some of the components that are rarely needed just got a tariff reduction.Sixty seven percent of world MRO expenditure for material procurement are for the procurement of new and original (OEM) components. Other expenses for use and serviceable material (USM), pool material outsourcing (PMA), and repairable parts. The high cost of procuring these new components shows the need to reduce prices so that domestic MROs can compete in the international market. The reduction in import duty to zero percent is very strategic to increase competitiveness, considering that $99 \%$ of aircraft components are imported commodities.

\section{Domestic MRO Competitiveness: Five Force Model}

The development of the MRO industry is inseparable from internal and external forces. The government targets, by 2020 Indonesia can enter the top 10 of $\mathrm{Asia}^{2}$. MRO industry in Indonesia has been recognized by the international aviation regulatory agencies or the Federal Aviaton Administration. However, the Indonesian MRO industry's human resources capabilities are still limited, moreover the lack of complete facilities also affect the competitiveness of domestic MROs.

\section{a) Threats of Newcomer MRO Company and AMO} Certified Foreign MRO

New MRO companies and expansion MRO companies are competitors for existing MROs. Besides having the potential to create oversupply (idle capacity for existing MROs), the development of MRO also has the potential competition to obtain expert human resources. The existence of the new MRO is a threat to the existing national MRO, especially the independent MRO (not integrated with the airline). But there are still opportunities to develop domestic MROs with specific capability specifications. Relatively cheap labor costs become Indonesia's comparative advantage.

By 2017, from 64 domestic MROs registered at AMO (Approval Maintenance Organization), only two MROs have engine capabilities, they are PT DI (for military) and Indonesian Aviation College (STPI) for training aircraft. While of the 65 AMO-certified foreign MROs, there are 7 MROs have engine capabilities. The absence of engine capability in the national MRO has caused engine maintenance carried out through outsourcing from foreign MRO. When the engine reenters Indonesia, subject to import regulation of not-new capital goods (Minister of Trade Regulation No.12/2018). Other aircraft components that require special treatment are tires and pooling components (spare parts). Not all airlines have their own spare parts pooling facilities due to costs considerations. Spare parts to be processed in pooling business are directly subject to import duties. The imposition of import duties can burden the pooling company's cash flow when compared to tax imposition when used on aircraft. These regulations reduce the competitiveness of the MRO for engine maintenance.

b) Bargaining Power of Customers and Suppliers MRO is a capital and labor intensive industry. The main suppliers needed by the MRO are aircraft components and human resources. Aircraft repairs cannot be 
automated, so the number of MRO human resources must be available with high competence. Currently $99 \%$ aircraft components are imported, Indonesia has been able to produce aircraft components for the non-critical component categories, but these components are license from an aircraft manufacturer whose purchase must be through an authorized overseas supplier (import). Import duties on aircraft components are also relatively high compared to European Union member countries which impose $0 \%$ import duty on all aircraft components.

\section{c) Threat of the Substitution Industry}

MRO is always needed as long as the aircraft operates. However, MRO faces changes in aircraft technology. The MRO industry is required to follow technological changes in providing services. Based on the manufacture year, CIF divided the aircraft into three generations, they are old, mature, and new generation [10]. Decreasing old and mature generation aircraft substituted with new generation whose population increased $32.7 \%$ per year. In 2021 , the new generation contributed estimated to $25 \%$ and in 2026 the dominance will be $47 \%$. New generation aircraft that implement eenable aircraft require different maintenance from the previous generation aircraft. Handling is taken over by OEMs and MRO integrators. OEM companies are collaborating with Microsoft and IBM to build analytical capabilities to serve AHM (Analytical Health Maintenance). Small-scale independent MROs, such as those in Indonesia, are difficult to obtain big data aircraft, so they cannot invest in AHM on new generation aircraft. The existing small MROs need to collaborate with OEMs or MRO integrators to survive in the new generation era.

\section{d) Level of Competitive Rivalry}

$\mathrm{MRO}$ is an international business, foreign MRO companies that continuously increase capacity and provision of facilities are the main competitors. Government support for the development of the MRO industry in Indonesia are realized through incentives of 21 post tariffs for aircraft components to $0 \%$, Minister of Finance Regulation (PMK) No. 35/2016 is an opportunity for the MRO industry to be able to compete with its competitors at the regional level; plans for the construction of integrated industrial zones in with supporting facilities such as airports, aircraft repair facilities, training of flight employees, as well as business and residential areas, industrial human resource development; and strengthening the aircraft component industry in collaboration with aircraft manufacturers, especially Airbus and Boeing in order to establish Aircraft Engineering Centers in Indonesia.

\section{Criteria for Priority Parts Exempt from Import Duty}

Aircraft spare parts as a whole are included in the $312 \mathrm{HS}$ code (6 digit) category. By 2015, with the addition of 21 tariff posts, aircraft spare parts obtained tariff exemption facilities were $92 \mathrm{HS}$ codes, so there were still $220 \mathrm{HS}$ whose import tariffs were not $0 \%$ yet. In order for tariff reduction not to disrupt government finances in terms of tax revenues and provide maximum benefits for MRO industry's competitiveness, hence it needed component criteria for prioritized in lowering the tariff. Selection of spare parts are prioritized to exempt import tariffs is carried out using AHP analysis based on stakeholder judgment. The hierarchy of spare parts criteria is shown in Figure 2, the hierarchy is arranged from the highest to the lowest level. The highest level is the focus, followed by the factors, actors and groups of alternative proposed parts. The principle of AHP assessment is pairwise comparisons the level of importance or influence of one element with other elements that in one level based on certain considerations. The value given is in the scale of opinion issued by Saaty [11]. The geometric mean of all respondents from each opinion value compared is processed using Expert Choice software. This analysis is used to interpret the priorities of the factors and actors that influence the selection of groups of spare parts whose import tariffs are exempted.

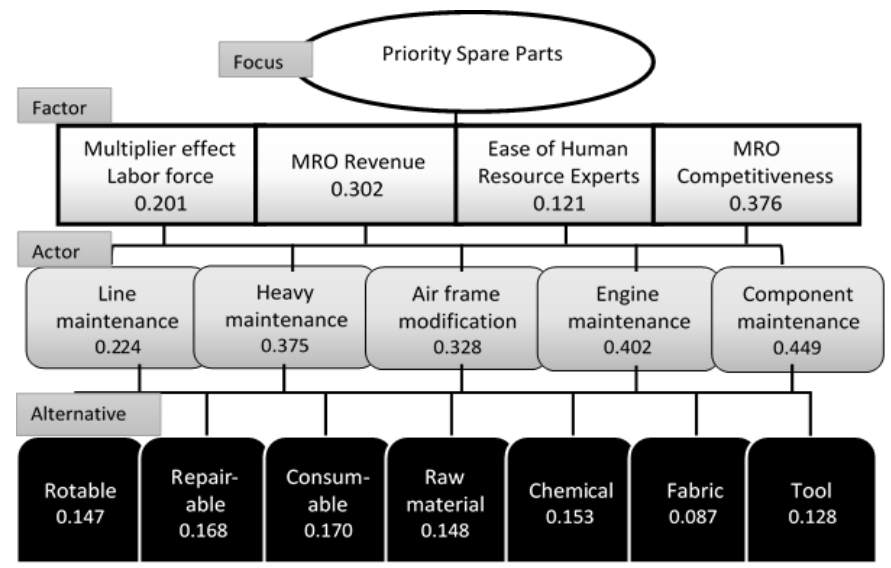

Fig. 2. AHP Spare Parts Hierarchy Diagram for Exempt Tariff

The result of AHP analysis is weighted at each level of the hierarchy. The weights and priorities analyzed are the results of a combination of stakeholders' opinions on each paired matrix. Based on the results of the FGD and in-depth interviews, composed of priority parts criteria to exempt the import tariff. Figure 3 to Figure 5 shows the priority order of policy criteria (factors and actors) and alternative spare parts. The value of the consistency ratio (CR), all below 10 percent so that it meets the requirements as stated by Saaty [8]. This means that there is consistency of assessments conducted by the respondents towards the criteria of policy makers.

\section{a) Factors Criteria Weighting}

Increased MRO's competitiveness and its service export is the main factor (highest value) in determining spare parts which are prioritized to be exempt from tariffs. If the national MRO has competitiveness, the MRO market will be wider and will have a positive impact on other factors.

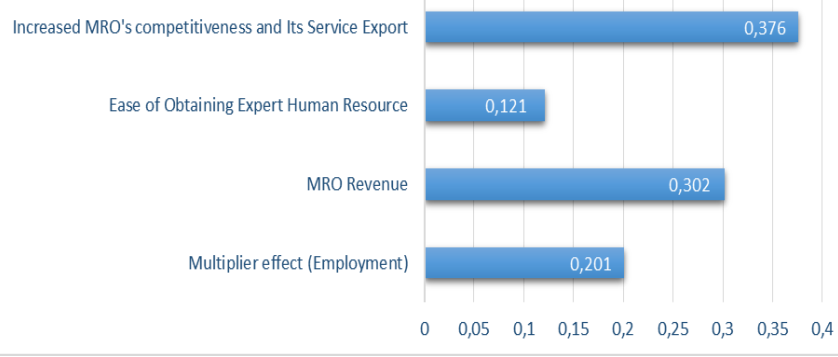

Fig. 3. Priority factor criteria from AHP results
Consistency ratio: 0.1 
MRO revenue is the main determinant of business sustainability. Positive revenue can be obtained if MRO operates on an economic scale because it requires very high investment capital [12]. The development of new capabilities, starting from the MRO's ability to supply spare parts for other MROs (logistics services). If logistics services are large enough, it is possible to develop new capabilities to achieve economics of scale. The multiplier effect on employment is not a major consideration in determining the components proposed to exempt tariffs. Domestic MRO capability, generally labor intensive to service old generation and mature generation aircraft who have not used big data like new generation aircraft, so if the competitiveness increases, MRO can develop new capabilities that aoutomaticly will absorb a lot of labor.

\section{b) Actor Criteria Weighting}

MRO's actors are represented by types of MRO's services (capability groups). Component maintenance is the most decisive capability group in choosing priority parts to be exempt the tariff.

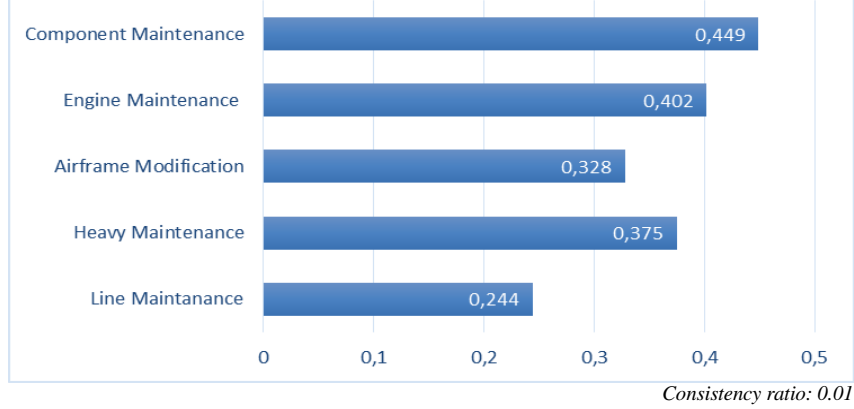

Fig. 4. Priority of Actor Criteria from AHP Results

Components maintenance are the main consideration in determining the priority parts to exempt tariff, because the parts turnover in components maintenance is relatively fast. Of the five capability groups, component maintenance and engine maintenance provide the highest benefits for MRO. In the cost structure of MRO, the highest material costs is for engine maintenance, the second is the component maintenance, while the airframe heavy maintenance and line maintenance, the largest cost is in labor [13]. MROcapability in the engine maintenance field is a source of profit for the MRO. Engine maintenance is routine maintenance should be done by the airline to get the civil administration registration certification. PK-registered old generation and mature generation aircraft require more intensive engines maintenance. Repairing aircraft engines was cheaper than buying a new engine, so the capability of MRO in engine maintenance was very beneficial for MRO revenue.

\section{c) Weighting of Input Criteria AHP Results}

The results of AHP analysis show that six of the seven alternative spare parts groups have almost the same weight values (ranging from 0.128 to 0.170 ). The main priority to be exempt the tariff is the consumable tool group $(0.17)$, the second priority is repairable with a weight of 0.168 . Both of these parts are widely used by MRO on the component maintenance and engine maintenance capabilities, the highest revenue contributor in the MRO industry.

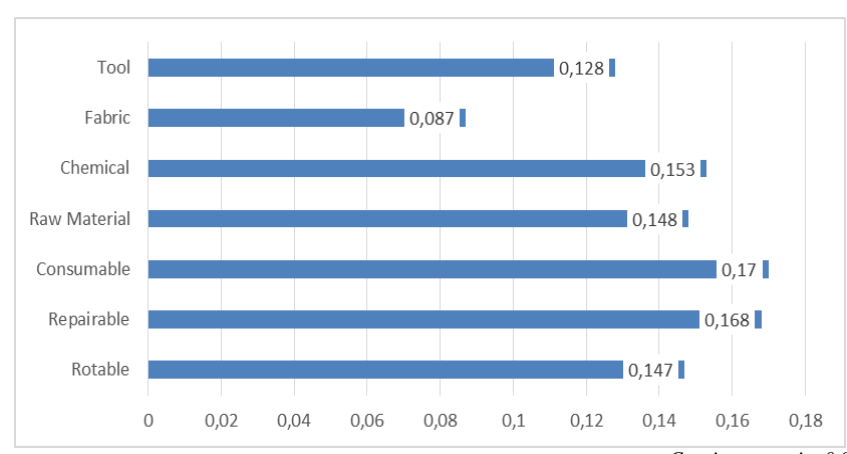

Fig. 5. Priority Spare Parts of AHP Results Consistency ratio: 0.02

\section{CONCLUSION AND RECOMMENDATION}

Based on the analysis it can be concluded that there is an increase in national MRO competitiveness after the import duty exemption policy, where in 2013 its contribution only reached $30 \%$, then in 2017 it increased to $51 \%$ or worth USD1.1 billion, while $49 \%$ still used foreign MRO services. The constraints encountered during the implementation of PMK No. 35/PMK.010/2016 are procedures and differences in customs areas where the longes is for bonded zones, so that the service does not reach minimum aircraft down time. The cause of the low competitiveness of the MRO industry is due to the lack capabilities of MRO (engine), has not reached the minimum aircraft down time, high costs especially for rotable/tire and repairable/machine/AC. Priority spare parts need to be exempted from import duties are consumable and repairable groups for component maintenance and engine maintenance capabilities in both new and non-new capital goods categories.

Policy recommendations in order to encourage competitiveness and the national aircraft MRO are: encourage cooperation among MROs in investment, resource and cooperation sharing in terms of components supply in pooling business form to increase capacity and capability, so it can reduce overhead costs; encourage MRO cooperation with aircraft manufacturers related to after-sales services; propose a $0 \%$ tariff reduction not based on the HS code but based on the serial number, or use the specific HS code for aircraft components; support the gradually import duty tariff exemption accordance the priority, where it's need additional tariff posts subject to import duty exemption, especially for groups of consumable and repairable goods; improve the custom clearance system; the tariff exemption procedure needs to be simplified to reach MRO customer down time.

\section{ACKNOWLEDGMENT}

This research was supported by Trade Analysis and Development Agency, Ministry of Trade of Republic of Indonesia. Special thank to our colleagues of Center for Foreign Trade, Umar Fakhrudin, Hasni, Yudi Fadilah, Nur Millah Yazthi, and Nova Aulia Bella, who provided insight and expertise that greatly assisted carry out the research.

\section{REFERENCES}

[1] Cooper, T., et al., "Global Fleet \& MRO Market Forecast Commentary", Olyver Wyman, 2018.

[2] Azka, R., D. and Nurcahyo, R., "Quality Management Strategy for Indonesian Aircraft MRO Companies Based on Kano Model, QFD Matrix, and AHP", International Conference on Industrial Engineering and Operations Management, pp. 1544-1555, 2018. 
[3] Al-kaabi, H., Potter, A. \& Naim, M, “An outsourcing decision model for airlines MRO activities, Journal of Quality in Maintenance Engineering, vol.13, pp. 217-227, 2007

[4] Wibowo, A., Tjahyono, B., \& Tomiyama, T., "Towards an Integrated Decision Making Framework for Aero Engine MRO Contract Management in the Productisation Context", Procedia CIRP 47, pp.24-29, 2016.

[5] Porter, M. E, "The Competitive Advantage: Creating and Sustaining Superior Performance", NY: Free Press, 1985. (Republished with a new introduction, 1998.)

[6] Thurlby, B., "Competitive forces are also subject to change. Management Decision", vol. 36(1), pp.19-24, 1998

[7] Porter, M. E., "The Five Competitive Forces that Shape Strategy. Harvard Business Review", vol 1 (1), pp 1-18, 2008

[8] Saaty, Thomas L.,"Pengambilan Keputusan bagi Para Pemimpin, Proses Hierarki Analitik untuk Pengambilan Keputusan dalam Situasi yang Kompleks", Jakarta: PT. Pustaka Binaman Pressindo, 1993.

[9] Kadarsah, S. and Ramdhani A., "Sistem Pendukung Keputusan: Suatu Wacana Struktural Idealisasi dan Implementasi Konsep Pengembangan Keputusan”, Bandung: Remaja Rosdakarya, 2000.

[10] Brown R, Principal, and A Diepeveen, "The Connected Fleet: Further Implications of Aircrfat Health Monitoring for the Aviation Supply Chain, Industry Insights". Aviation Briefing Prepared by ICF for ALTA $20171^{\text {st }} \mathrm{Ed}, 2017$.

[11] Saaty, Thomas L., "How to make a decision: the analytic hierarchy process", Institute for Operations Research and the Management Science, vol. 24 (6), pp.19-43, 1994.

[12] McFadden, M. and DS, Worrels, "Global Outsourcing of Aircraft Maintenance", Journal of Aviation Technology and Engineering, vol. 1 (2), pp.63-73, 2012.

[13] Budihadianto, R., "Bisnis MRO; Harapan Baru Perekonomian Indonesia”, Jakarta: GMF AeroAsia, 2015. 